\title{
EFEKTIFITAS KONSELING TEKNIK KREATIF DALAM MEREDUKSI PERILAKU AGRESIF SISWA DI SMAN 9 KOTA JAMBI
}

\author{
ZAKARIA HARAHAP \\ SMA Negeri 9 Kota Jambi Provinsi Jambi \\ zharahap1967@gmail.com
}

\begin{abstract}
ABSTRAK
Tujuan penelitian ini adalah untuk mengurangi perilaku Agresif siswa melalui Bimbingan Kelompok dengan Konseling Teknik Kreatif Dalam Mengurangi Perilaku Agresif Siswa Kelas XII IPS 1 SMA Negeri 9 Kota Jambi. Penelitian ini menggunakan Pre-eksperimental design, yaitu one-group pretest dan posttest. Populasi siswa dalam penelitian ini adalah siswa Kelas XII IPS 1 SMA Negeri 9 Kota Jambi dengan sampel berjumlah 35 siswa. Berdasaarkan hasil skor angket skala perilaku Agresif diambil sampel 6 orang siswa yang memiliki skor tertinggi dan 2 orang siswa skor rendah untuk diberikan perlakuan layanan bimbingan kelompok dengan teknik konseling kreatif. Setelah itu akan dibandingkan keadaan sebelum dan sesudah diberi perlakuan. Data hasil penelitian ini dianalisis menggunakan uji wilcoxon. Berdasarkan analisis maka diperoleh data bahwa tingkat perilaku Agresif siswa setelah diberikan layanan bimbingan kelompok dengan konseling teknik kreatif rata-rata 230 (61\%). Perubahan sebelum dan sesudah diberikan layanan bimbingan kelompok dengan konseling teknik kreatif mengalami peningkatan sebanyak skor -63 (19\%). Hasil perhitungan uji Wilcoxon pada data keseluruhan siswa, diperoleh hasil bahwa nilai signifikasi (Sig). sebesar 0,012 kurang dari 0,05. Hal ini berarti terdapat perbedaan antara hasil pre-test dan post-test menggunakan layanan bimbingan kelompok dengan teknik konseling kreatif, atau dapat dikatakan bahwa ada pengaruh dari layanan bimbingan kelompok.
\end{abstract}

Kata Kunci: Inkuiri, minat baca, pengetahun

\section{PENDAHULUAN}

Pendidikan dalam penyelenggaraannya di Indonesia adalah dihajatkan untuk membangun manusianya baik dari segi pengetahuan, ekonomi, hukum sampai dengan perilaku. Inti dari pendidikan di Indonesia adalah memanusiakan manusia atau menjadikan manusia menjadi sosok yang utuh baik dari segi pikiran, pengetahuan dan perilaku yang beradab. Definisi pendidikan secara mendasar adalah usaha sadar untuk mempersiapkan peserta didik melalui kegiatan pengajaran, bimbingan atau latihan bagi perannya dimasa yang akan datang". Pendidikan yaitu suatu fondasi bagi setiap orang, yang dimana pendidikan sangat di butuhkan untuk mencerdaskan kehidupan bangsa, setiap orang mempunyai hak yang sama untuk mendapatkan pendidikan yang layak, oleh sebab itu pendidikan merupakan hal yang utama yang dapat memajukan sumber daya manusia di Indonesia, terutama para generasi muda, khususnya para peserta didik yang ada disekolah, seperti siswa-siswi yang dalam proses belajar pembelajarannya sering kali menunjukkan berbagai macam perilaku, contohnya dalam bergaul sehari-hari menunjukkan perilaku yang biasa dikatakan agresif. Seperti agresif dalam belajar, agresif dalam berkata, agresif dalam bertindak, dan agresif dalam mengganggu teman sebayanya.

Sekolah merupakan sumber pendidikan kedua setelah lingkungan keluarga bagi anak remaja. Selama mereka menempuh pendidikan terjadi interaksi antara remaja denga sesamanya. Interaksi yang mereka lakukan di sekolah sering menimbulkan akibat sampingan yang negatif bagi perkembangan mental anak remaja. Namun disekolah pula yang paling banyak terjadi tindakan kekerasaan, secara verbal (mencaci maki, mengancam dan memerintah orang lain) maupun nonverbal/kekerasan fisik (memukul, meninju, menginjak, mencubit) dengan perorangan maupun secara berkelompok disebut "Perilaku Agresif". seperti yang dinyatakan Myres (2012: 33) bahwa agresi (aggression) adalah perilaku individu yang menampilkan baik dalam bentuk fisik maupun lisan yang dimaksudkan untuk menyebabkan kerusakan. 
Perilaku agresif adalah perilaku fisik atau verbal yang dimaksudkan untuk merusak atau melukai orang lain. Perilaku agresif merupakan perbuatan yang mengakibatkan orang lain mengalami penderitaan, sehingga mendatangkan kesusahan baik fisik maupun psikologis. Firman (2016) menjelaskan bahwa perilaku agresif disebabkan oleh persoalan kecil, seperti kesalahpahaman, ketidakpuasan, dan pertengkaran yang berakhir dengan pembunuhan, pembakaran, serta merusak fasilitas milik pribadi maupun umum. Berbagai peristiwa tindakan kekerasan dan agresivitas yang menggemparkan dilakukan oleh siswa sekolah menengah. Komisi Perlindungan Anak Indonesia (KPAI) saat ini mencatat ada 3000 lebih kasus kekerasan dalam kurun waktu selama tahun 2016-2020. Selanjutnya perilaku agresif tidak hanya dilakukan di Indonesia, tetapi juga dibanyak negara seperti Amerika Serikat. Menurut Puzzanchera, Stahl, Finnegan, Tierney, dan Snyder dalam Saputra, dkk (2017) perilaku agresif berdasarkan gender antara tahun 1985 sampai 2000 terjadi pada anak laki- laki sebesar 34\%, sedangkan pada anak perempuan yang terlibat sebesar $83 \%$.

Perilaku agresif di kalangan remaja khususnya pelajar semakin meningkat baik dari jumlah maupun variasi bentuk perilaku yang dimunculkan, hal ini menggambarkan bahwa para siswa memiliki control diri yang lemah dan berhubungan negatif dengan kecendrungan berperilaku termasuk di dalamnya perilaku agresif. Adanya perilaku agresif dalam remaja karena banyak faktor yang menyebabkan, berikut ini adalah pengaruhi dan pemicu munculnya sikap agresif bagi remaja, seperti faktor biologis, sikap temperamen, pergaulan yang negatif, pola asuh orang tua, pengaruh tayangan kekerasan dan lainnya. Pikiran dan interpresasi seseorang mengenai kejadian eksternal yang juga mempengaruhi emosi dan perilakunya. Perilaku agresif tidak hanya dipicu dengan adanya kejadian-kejadian di lingkungan individu namun juga dimunculkan dari bagaimana kejadian tersebut diterima dan diproses secara kognitif. Remaja yang pemarah dan agresif seringkali mengalami bias dan atribusi, terutama dalam mempersepsi situasi-situasi sosial, dan hal ini mendorong mereka untuk berperilaku agresif ketika menghadapi konflik atau kondisi yang tidak menyenangkan (Gunawan, dkk, 2020).

Anantasari dalam Nafiah, dkk (2014) menjelaskan bahwa bahwa perilaku agresif adalah segala bentuk perilaku yang disengaja terhadap orang lain maupun objek lain dengan tujuan merugikan, mengganggu, melukai ataupun mencelakaan korban baik secara fisik maupun psikis, langsung maupun tidak langsung. Dapat dikatakan bahwa Perilaku agresif muncul karena siswa tidak mendapatkan sesuatu yang diinginkan sehingga dapat timbul luapan emosi dalam bentuk verbal dan nonverbal. Apabila keadaan demikian terus menerus dibiarkan dan tidak segera diatasi, disamping dapat menganggu proses pembelajaran juga akan menyebabkan siswa cenderung untuk beradaptasi kebiasaan buruk dan membudaya yang akhirnya akan merugikan bagi siswa dan lingkup sosial (Dwi, 2019).

Maka dalam memecahkan masalah tersebut, dibutuhkan upaya terapi yang mampu mengembalikan keadaan psikologi dan tingkah laku siswa menjadi seperti semula. Adapun langkah tersebut yakni melaksanakan konseling. Konseling merupakan suatu proses pemberian bantuan yang dilakukan konselor kepada konseli untuk dapat mengatasi permasalahan yang ada pada diri konseli. Hasilnya diharapkan timbul suatu perilaku baru yang bisa menjadi patokan diri konseli untuk bertindak kemana selanjutnya konseli melangkah (Talambanua, 2020). Pelaksanaan layanan bimbingan di sekolah merupakan salah satu upaya pecegahan perilaku agresif. Dalam proses konseling pencegahan perilaku agresif diusahakan melalui suatu proses belajar (learning) atau belajar kembali (relearning).

Oleh karena itu proses konseling dipandang sebagai suatu proses pendidikan (an educational process) yang berpusat pada usaha membantu dan kesediaan dibantu untuk belajar perilaku baru dan dapat mengatasi permasalahan yang ada (Karneli, dkk, 2018). Masalah perilaku agresif merupakan suatu fenomena yang menarik untuk diteliti. Berbagai pendekatan dapat dilakukan guru dan sekolah untuk mengurangi permasalahan siswa tentang perilaku agresif diri diantaranya adalah dengan menggunakan konseling teknik kreatif. Guru 
$\mathrm{BK} /$ konselor yang kreatif diharapkan mampu memberikan layanan dalam rangka mencapai perkembangan optimal dan kemandirian yang utuh. Guru BK/konselor yang kreatif mampu mengentaskan berbagai macam masalah siswa yang berkembang di sekolah antara lain mampu mencegah tindakan kekerasan dan menurunkan tingkah laku agresif siswa yang terjadi di sekolah.

Namun Jacob (dalam Hasibuan, 2018) berpendapat bahwasannya terdapat 7 kesalahan yang umum dilakukan konselor yang menyebabkan sesi konseling menjadi membosankan dan tidak efektif, yaitu: (1) Melakukan terlalu banyak refleksi; (2) Mendengarkan terlalu banyak cerita konseli; (3) Jarang menginterupsi konseli; (4) Tidak fokus dalam sesi konseling; (5) Menunggu terlalu lama untuk melakukan fokus; (6) Tidak menggunakan teori konseling, menggunakan "hope method" dalam konseling (7) Jarang menggunakan alat bantu yang kreatif dan tidak bersifat multisensori. Untuk itu di dalam proses konseling diperlukan sebuah kreativitas yang mampu membuat klien merasa nyaman dengan tahapan pelaksanaan konseling, karena konseling kreatif dapat meningkatkan efektivitas konseling. Menurut Conte (dalam Hasibuan, 2018) Konseling kreatif merupakan suatu pendekatan konseling yang unik karena pendekatan kreatif dalam konseling menawarkan sebuah energi baru pada klien untuk dapat meningkatkan sensivitas pada dirinya dan orang lain.

Menurut Conte (dalam Engel, 2017) konseling kreatif merupakan suatu pendekatan konseling yang unik karena pendekatan kreatif dalam konseling menawarkan sebuah energi baru pada klien untuk dapat meningkatkan sensivitas pada dirinya dan orang lain. Ketika klien lebih sensitif terhadap diri mereka sendiri itu dapat mendorong mereka untuk berinvestasi dalam proses terapi yang dapat membantu mereka tumbuh dan berkembang lebih baik (A. Kennedy dalam Gladding, 2016:2). Ada beberapa alasan mengapa dalam konseling layak menggunakan konseling kreatif, pertama seni yang dilakukan dalam konseling adalah sarana utama atau membantu individu untuk menjadi lebih memahami diri sendiri untuk memahami pikiran dan tubuh mereka. Kedua seni melibatkan energi dan proses. Adanya energi maka membantu individu untuk memperkuat energi dan menumbuhkan energi baru pada individu tersebut (Kusuma, 2019).

Dalam penelitian ini, peneliti mengadopsi teknik konseling yang akan digunakan yaitu konseling kreatif. Konseling kreatif merupakan suatu pendekatan konseling yang unik karena pendekatan kreatif dalam konseling menawarkan sebuah energi baru pada klien untuk dapat meningkatkan sensivitas pada dirinya dan orang lain (Lubis, 2018).

Guru Bimbingan Konseling di sekolah tentunya sudah melakukan usaha dalam mengatasi masalah siswa dalam menurunkan agresifitas siswa di depan kelas, namun belum terselesaikan dengan efektif. Maka, dengan menggunakan konseling kreatif sebagai teknik baru bisa membantu siswa dalam mengentaskan masalahnya. Selama sesi konseling, konselor secara kreatif berupaya melibatkan konseli dalam memahami masalah dari berbagai perspektif. Saat konselor dan konseli berurusan dengan ide-ide abstrak atau isu yang ambigu, konselor berupaya mengkonkritkan ide atau isu tersebut. Hal ini berimplikasi pada pentingnya penggunaan beragam teknik kreatif dan metafora dalam konseling (Lumban, 2018).

Berdasarkan fakta lapangan saat melakukan studi pendahuluan terhadap perilaku agresif di sekolah SMA Negeri 9 Kota Jambi yang diperoleh dari angket yang disebarkan pada tanggal 6 November 2019 di 3 kelas dengan jumlah siswa 113 orang siswa diketahui siswa mengalami masalah dalam interaksi sosialnya di sekolah. Siswa yang menunjukkan kecenderungan berperilaku agresif mencapai angka sebesar 44,68\%. hasil yang didapatkan sementara menunjukan adanya perilaku agresif berupa mengejek, mengolok, menendang, memukul, menampar dan sebagainya. Hal tersebut sudah memasuki ranah perilaku agresif pada siswa.

Berdasarkan uraian di atas perilaku agresif ini bila tidak segera ditangani dihawatirkan akan mengakibatkan hal-hal yang tidak diinginkan atau lebih membahayakan bagi siswa. Oleh karena itu peneliti ingin berusaha untuk menggurangi atau bahkan menghilangkan perilaku angesif dengan menggunakan Layanan Bimbingan Kelompok berupa Layanan Konseling Teknik Kreatif. 


\section{METODE PENELITIAN}

Penelitian ini menggunakan Pre-eksperimental design, yaitu one-group pretest dan posttest dimana dalam rancangan ini terdapat hanya satu kelompok objek yaitu kelompok eksperimen sebagaikelompok yang dikenakan perlakuan. Pretest adalah sebelum siswa diberikan perlakuan kemudian sesudah diberi perlakuan atau posttest. Teknik pengumpulan data menggunakan Kuesioner dengan model skala likert.

Populasi dalam penelitian ini adalah Siswa Kelas XII IPS 1 SMA Negeri 9 Kota Jambi dengan sampel adalah siswa yang memiliki perilaku agresif mengganggu teman pada kelas XII IPS 1 di SMA Negeri 9 Kota Jambi tahun pelajaran 2019/2020. Penelitian ini dilakukan selama 2 bulan mulai dari bulan November sampai dengan Desember 2019. Karena penelitian menggunakan konseling perlakuan penelitian, maka menggunakan metode purposive sampling yaitu metode penentuan sampel dengan pertimbangan khusus sehingga layak dijadikan sampel (Lumonggo, dkk, 2016). Berdasarkan hasil skor angket skala perilaku Agresif diambil sampel 8 orang siswa yang memiliki skor tertinggi untuk diberikan perlakuan layanan bimbingan kelompok dengan layanan teknik kreatif, Setelah itu akan dibandingkan keadaan sebelum dan sesudah diberi perlakuan dengan menggunakan Analisis Uji Wilcoxon. digunakan untuk memperoleh data adalah 8 siswa yang memiliki skor perilaku agresif tinggi. Instrumen yang digunakan dalam penelitian ini adalah sngket dengan didukung pedoman observasi, wawancara, dan dokumentasi. Adapun teknik analisis data yang diguanakan yakni analisis statistik dengan rumus t-test.

\section{HASIL DAN PEMBAHASAN}

Perilaku Agresif Siswa Kelas XII IPS 1 di SMAN 9 Kota Jambi Sebelum diberikan Layanan Bimbingan Kelompok Konseling Teknik Kreatif.

Hasil pengisian skala perilaku Agresif 8 orang siswa Kelas XII IPS 1 di SMAN 9 Kota Jambi sebelum diberikan layanan bimbingan kelompok Konseling Teknik Kreatif dapat dilihat pada tabel dibawah ini:

Tabel 1 Skor Pre-test sebelum dilakukan treatment

\begin{tabular}{lcc}
\hline Nama & Pretest & Kategori \\
\hline II & 318 & T \\
\hline LAS & 324 & T \\
\hline AT & 316 & T \\
\hline MYR & 311 & T \\
\hline MRN & 309 & T \\
\hline H & 307 & T \\
\hline MAH & 232 & R \\
\hline SNK & 227 & R
\end{tabular}

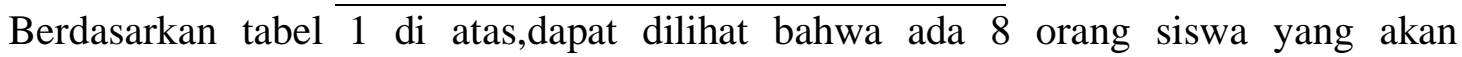
mendapatkan Treatment diantaranya 6 siswa dengan kategori perilaku agresif tinggi, dan 2 siswa dengan kategori perilaku agresif rendah.

\section{Perilaku Agresif Siswa Kelas XII IPS 1 di SMAN 9 Kota Jambi Sebelum diberikan Layanan Bimbingan Kelompok Konseling Teknik Kreatif.}

Adapun Tingkat Perilaku agresif siswa sesudah diberikan treatment berupa Layanan Bimbingan Kelompok Konseling Teknik Kreatif pada Kelas XII IPS 1 di SMAN 9 Kota Jambi adalah sebagai berikut:

Tabel 2. Hasil Pos-test Setelah Treatment

\begin{tabular}{clc}
\hline Nama & Post-test & Kategori \\
\hline II & 261 & S \\
\hline LAS & 243 & S \\
\hline AT & 249 & S \\
\hline
\end{tabular}




\begin{tabular}{ccc}
\hline MYR & 286 & $\mathrm{~S}$ \\
\hline MRN & 235 & $\mathrm{R}$ \\
\hline $\mathrm{H}$ & 269 & $\mathrm{~S}$ \\
\hline MAH & 157 & SR \\
\hline SNK & 143 & SR \\
\hline
\end{tabular}

Berdasarkan tabel 2 maka dapat dilihat bahwa hasil Post-test rata-rata berada dikategori sedang, rendah dan sangat rendah setelah diberikan perlakuan layanan bimbingan kelompok dengan konseling teknik kreatif sehingga mengalami penurunan.

Tabel 3. Tingkat Perilaku Agresif Siswa Sebelum dan Sesudah diberikan Treatment

\begin{tabular}{ccccccc}
\hline $\begin{array}{c}\text { Nam } \\
\text { a }\end{array}$ & Pre-test & $\begin{array}{c}\text { Katego } \\
\text { ri }\end{array}$ & $\begin{array}{c}\text { Post- } \\
\text { test }\end{array}$ & Kategori & Progres & $\%$ \\
\hline II & 318 & $\mathrm{~T}$ & 261 & $\mathrm{~S}$ & -57 & $15 \%$ \\
LAS & 324 & $\mathrm{~T}$ & 243 & $\mathrm{~S}$ & -81 & $21 \%$ \\
AT & 316 & $\mathrm{~T}$ & 249 & $\mathrm{~S}$ & -67 & $19 \%$ \\
MYR & 311 & $\mathrm{~T}$ & 286 & $\mathrm{~S}$ & -25 & $7 \%$ \\
MRN & 309 & $\mathrm{~T}$ & 235 & $\mathrm{R}$ & -76 & $20 \%$ \\
H & 307 & $\mathrm{~T}$ & 269 & $\mathrm{~S}$ & -38 & $10 \%$ \\
MAH & 232 & $\mathrm{R}$ & 157 & SR & -75 & $20 \%$ \\
SNK & 227 & $\mathrm{R}$ & 143 & SR & -84 & $23 \%$ \\
\hline
\end{tabular}

Berdasarkan tabel 3 di atas peneliti dapat menjelaskan bahwa setiap anggota kelompok mengalami peningkatan skor. Skor yang rendah menunjukan perilaku agresif yang tinggi, namun setelah diberikan layanan bimbingan kelompok dengan konseling teknik kreatif pada siswa Kelas XII IPS 1 di SMAN 9 Kota Jambi, Terlihat perubahan yang awalnya rendah mengalami peningkatan skor. Siswa inisial II memperoleh hasil pre-test 318 masuk kategori Sedang kemudian setelah treatment memperoleh hasil post-test 261 yang berarti mengalami peningkatan skor sebesar $-57(15 \%)$. Siswa inisial LAS memperoleh hasil pre-tes 324 kemudian setelah treatment hasil post-test 243 berarti terjadi peningkatan sebesar $-81(21 \%)$. Siswa inisial AT hasil pre-test 316 kemudian setelah treatment hasil post-test 249 berarti terjadi peningkatan sebesar -67 (19\%). Siswa MYR hasil pre-test 311 kemudian setelah treatment hasil post-test 286 berarti terjadi peningkatan skor sebesar -25 (7\%). Siswa inisial MRN hasil pretest 309 kemudian setelah treatment 235 berarti terjadi peningkatan sebesar -76 (20\%). Siswa inisial $\mathrm{H}$ hasil pre-test 307 kemudian setelah treatment hasil post-test 269 berarti terjadi peningkatan sebesar -38(10\%). Siswa inisial MAH hasil pre-test 232 kemudian setelah treatment hasil post-test 157 berarti terjadi peningkatan skor sebesar -75(20\%). Siswa inisial SNK hasil pre-test 227 kemudian setelah treatment hasil post-test 143 berarti terjadi peningkatan skor sebesar - 83(19\%).

\section{Analisis Uji Wilcoxon}

Untuk memmbuktikan hipotesis yang diajukan pada penelitian ini yaitu layanan bimbingan kelompok dengan konseling teknik kreatif maka diadakan uji dengan Wilcoxon dengan bantuan aplikasi spss 23 maka hasil dapat dilihat pada tabel dibawah ini;

\begin{tabular}{llllll} 
& \multicolumn{3}{c}{ Ranks } & & \\
\hline & & & $\begin{array}{c}\text { Mean } \\
\text { Rank } \\
\text { Post-test } \\
- \text { Pre-test }\end{array}$ & $\begin{array}{c}\text { of } \\
\text { Ranks }\end{array}$ \\
\cline { 2 - 3 } & $\begin{array}{l}\text { Negative } \\
\text { Ranks } \\
\text { Positive } \\
\text { Ranks }\end{array}$ & $0^{\mathrm{a}}$ & 0.00 & 0.00 \\
& $8^{\mathrm{b}}$ & 4.50 & 36.00
\end{tabular}


$\begin{array}{lc}\text { Ties } & 0^{\mathrm{c}} \\ \text { Total } & 8\end{array}$
a. Post-test $<$ Pre-test
b. Post-test $>$ Pre-test
c. Post-test $=$ Pre-test

\begin{tabular}{lr}
\hline & \multicolumn{2}{c}{ Post-test - Pre- } \\
\cline { 1 - 1 } test & $-2,521^{\mathrm{b}}$ \\
$\mathrm{Z}$ & .012 \\
Asym & \\
p.Sig. & \\
$(2-$ & \\
tailed) & \\
1. a. Wilcoxon Signed Ranks \\
Test \\
2. b. Based on negative ranks.
\end{tabular}

\section{Wilcoxon Signed Rank Test}

Berdasarkan hasil perhitungan uji Wilcoxon pada data keseluruhan siswa diperoleh bahwa nilai signifikasi (Sig). sebesar 0,012 kurang dari 0,05. Hal ini berarti terdapat perbedaan antara hasil pre-test (293) dan post-test (260) dengan menggunakan layanan bimbingan kelompok dengan konseling teknik kreatif, atau dapat dikatakan bahwa ada pengaruh dari layanan bimbingan kelompok dengan konseling teknik kreatif. Sehingga terjadi penurunan prilaku agresif pada siswa kelas XII IPS 1 SMA Negeri 9 Kota Jambi.

\section{KESIMPULAN \\ Simpulan}

Berdasarkan pada hasil penelitian di atas maka dapat disimpulkan sebagai berikut: Bahwa Tingkat perilaku agresif siswa sebelum diberikan layanan bimbingan kelompok dengan konseling teknik kreatif rata-rata 293 (78\%). Tingkat perilaku Agresif siswa setelah diberikan layanan bimbingan kelompok dengan konseling teknik kreatif rata-rata 230 (61\%). Perubahan sebelum dan sesudah diberikan layanan bimbingan kelompok dengan konseling teknik kreatif mengalami peningkatan sebanyak skor -63 (19\%). Hasil perhitungan uji Wilcoxon pada data keseluruhan siswa, diperoleh hasil bahwa nilai signifikasi (Sig). sebesar 0,012 kurang dari 0,05. Setelah dilakukan pengujian dengan rumus Wilcoxon terbukti bahwa layanan bimbingan konseling dengan konseling teknik kreatif dapat mengurangi perilaku agresif pada siswa kelas XII IPS 1 SMA Negeri 9 Kota Jambi Provinsi Jambi tahun pelajaran 2019/2020.

\section{Saran}

Berdasarkan pada hasil penelitian di atas, berkaitan dengan hal tersebut peneliti dapat memberikan saran: Kepada siswa diharapkan dapat menurunkan perilaku agresif. Agar mencapai perilaku agresif yang stabil, hendaknya siswa mengikuti layanan bimbingan kelompok dengan konseling teknik kreatif dengan sungguh-sungguh agar dapat mengembangkan diri serta dapat mengendalikan perasaan dengan baik sehingga akhirnya dapat menurunkan perilaku agresif. Kepada Guru Bimbingan dan konseling hendaknya menerapkan layanan bimbingan kelompok dengan konseling teknik kreatif sebagai upaya dalam mengurangi perilaku agresif siswa, karena dengan layanan ini dapat membantu siswa yang memiliki tingkat agresifitas yang tinggi. diharapkan setelah diberikan layanan bimbingan kelompok dengan konseling teknik kreatif dapat menjadi lebih baik lagi dan perilaku agresif siswa bisa menurun bahkan mungkin bisa dihilangkan perilaku tersebut. 


\section{DAFTAR PUSTAKA}

Dwi, Y. (2019). Konseling Kelompok dengan Teknik Psikodrama "Nilai Karakter Cinta Damai" untuk Mereduksi Perilaku Agresif Siswa. Emphaty Cons-Journal of Guidance and Counseling, 1(1), 32-43.

Engel, J. D. (2017). Konseling Traumatik Dengan Pendekatan Logoterapi (Penanganan Terhadappost-Traumatic Stress Disorder (Ptsd) Korban Trafficking). PROCEEDING IAIN Batusangkar, 1(1), 114-126.

Firman, F. (2016). Penanggulangan Tindakan Kekerasan dan Agresivitas Remaja Remaja Kota Padang. Padang: FIP UNP.

Glading. T. Samuel. (2016). The Creative Art Counseling. New York: American Counseling Asociation.

Gunawan, I. M., Hartati, A., \& Mulachela, F. S. (2020). Pengaruh Konseling Kelompok Terhadap Perilaku Agresif Siswa di SMKN 4 Mataram. Jurnal Paedagogy, 7(4), 385392.

HASIBUAN, A. (2018). Pengaruh Konseling Kelompok Teknik Kreatif Terhadap Penyesuaian Diri Dengan Teman Sebaya Pada Siswa Kelas Xi Ips Sma Negeri 21 Medan Tahun Ajaran 2018/2019 (Doctoral dissertation, UNIMED).

Karneli, Y., Firman, F., \& Netrawati, N. (2018). Upaya Guru BK/Konselor untuk menurunkan perilaku agresif siswa dengan menggunakan konseling kreatif dalam bingkai modifikasi kognitif perilaku. Pedagogi: Jurnal Ilmu Pendidikan, 18(2), 113-118.

Kusuma, W. (2019). Pengaruh Konseling Kreatif Teknik Musik-Writing dan Forgiveness Terhadap Kebahagiaan Remaja Panti Asuhan Yayasan Amal Al-Washliyah Geding Johor Medan (Doctoral dissertation, Universitas Medan Area).

Lubis, A. A. S. (2018). Pengaruh Konseling Kelompok Teknik Kreatif Terhadap Self Esteem Pada Siswa Kelas Viii Smp Negeri 16 Medan Tahun Ajaran 2018/2019 (Doctoral dissertation, UNIMED).

LUMBAN GAOL, A. R. (2018). Pengaruh Konseling Kelompok Teknik Kreatif Terhadap Kecemasan Berbicara Di Depan Kelas Siswa Kelas Viii Smp Negeri 16 Medan Tahun Ajaran 2018/2019 (Doctoral dissertation, UNIMED).

Lumongga Lubis dan Hasnida. (2016). Konseling Kelompok. Jakarta: Kharisma Putra Utama.

Myres, D.G. (2012). Psikologi Sosial. Jakarta: Salemba Humanika.

Nafiah, A., \& Handayani, A. (2014). Layanan bimbingan kelompok dengan teknik homeroom untuk penurunan perilaku agresif siswa. Empati-Jurnal Bimbingan dan Konseling, 1(1).

Saputra, W. N. E., Hanifah, N., \& Widagdo, D. N. (2017). Perbedaan Tingkat Perilaku Agresi Berdasarkan Jenis Kelamin pada Siswa Sekolah Menengah Kejuruan Kota Yogyakarta. Jurnal Kajian Bimbingan Dan Kon, 2, 142-147.

Talambanua, S. (2020). Pengaruh Konseling Kreatif Teknik Guided Imagery terhadap Academic Anxiety Mahasiswa terhadap Skripsi di Jurusan Psikologi Pendidikan dan Bimbingan Universitas Negeri Medan (Doctoral dissertation, UNIMED). 